\title{
THE INFLUENCE OF ENTREPRENEURIAL SKILLS, EDUCATION AND RISK PERCEPTION ON CAREER CHOICE INTENT: THE CASE OF EUROPEAN STUDENTS WITH FAMILY BUSINESS BACKGROUND
}

\author{
Predrag Ljubotina \\ School of advanced social studies, Slovenia \\ E-mail: predrag.ljubotina@gmail.com
}

\begin{abstract}
When confronted with career choice, students with family business background have a specific trilemma. Having an additional career alternative as a potential family business successor, makes their career choice decision more complex compared with their peers. The purpose of this paper is to investigate how entrepreneurial education, risk perception and skill mastering influence career choice intention of this specific group of students. We used a data set from GUESSS 2014 survey. Our sample includes students with family business background from 18 European countries. We used a multinomial logistic regression since our dependant variable has three categorical solutions (entrepreneur, employee and successor). Our findings may be used by consultants, education institutions and more importantly by parents which find themselves in a triple role of an entrepreneur, an owner and a parent.
\end{abstract}

Key-words: family business, students, career choice, education, risk, entrepreneurial skills, succession

\section{Introduction}

Career choice is a frequently investigated issue in recent years since our socio-economic environment becomes more and more complex. Young people form an interesting investigation target group since they are close to making a career decision in such an environment. Previous studies confirmed that many factors shape individual's career decision. These studies are usually focused on two major alternatives: entrepreneurial career or an employment's path. This approach, however, leaves a huge research gap when speaking about students with family business background. Their situation is different if compared with their peers, since they are confronted with a trilemma with an additional career alternative of accepting the role of a family business successor. There are no instruments in the existing 
literature, which directly address this topic (Birley 2002). We lack a deeper understanding of potential heir's career choice intention, which precedes the decision itself (Ajzen 1991). That is one of the reasons for the importance of recognizing individual's entrepreneurial intentions in modern economies (Wennekers et al. 2005). Yet another argument strongly supports the need for investigating young potential family business heir's career intentions. Previous investigations found that there is a big gap between existing owners' expectations toward their children succession intention where $67 \%$ expect that potential heir will accept the role of a successor and their children where only $22 \%$ is actually considering that career alternative (Ernst\&Young 2012).

Family business played an important role throughout development of civilizations. Nowadays families are running small businesses as well as large multinational corporations (Bird et al. 2002). They all contribute significantly to countries GDP (Bindu Kota and Singh 2016). Given this worldwide economic and social relevance provided by family firms, understanding a potential heir's career choice motives is highly important for insuring the long-time business stability (Astrachan and Carey Shanker 2003). The lack of potential successor's motivation is the most frequent reason for unsuccessful family business transition process (De Massis, Chua, and Chrisman 2008). Family succession is of critical importance for family firm's transgenerational sustainability (Sharma, Chrisman, and Chua 2003).

Several factors influence career choice intentions. They can be categorized into three groups: individual, social and economic (Dyer 1994). The succession process should be analyzed through the prism of the owner, the successor and the environment (Lucky, Minai, and Isaiah 2011). In this paper, we are focused on individual factors of the potential young successor. Students are particularly interesting target group, since they are approaching a point where an actual career decision has to be made. We already know that most people will likely start their own business between the age of 24 and 44 (Liles 1974).

If universities are providing entrepreneurial knowledge, students are keener to choose entrepreneurial career path (Turker and Selcuk 2009). From this perspective, universities may be a potential source of new entrepreneurs. Entrepreneurship is not suitable for all young people, despite the fact that it is full of opportunities. This problem requires considering several aspects like entrepreneurial skill mastery, family legacies, labor market and political environment (O'Reilly et al. 2015). Entrepreneurial skills are gaining importance in today's competitive environment. Being able of controlling organization development, accumulation, innovations and other tasks is of crucial importance. A capable individual with a range of well 
controlled entrepreneurial skills will more likely successfully manage the company on turbulent market. Individuals also strongly consider risk when making their career decision since self-employment intention is significantly related to individual's risk attitude (Douglas and Shepherd 2002). Risk taking in closely related to entrepreneurship. Its impact on family business is particularly strong since family business success and family wealth constantly interlace. Since ownership and management are usually not clearly separated in family businesses, these firms handle the risk in a specific manner (Senegović, Bublić, and Ćorić 2015). Since family firm is already developed to a certain level, it is considered to be less risky than a new start-up (Laspita et al. 2012).

In this paper we investigate the influence of entrepreneurial education, individual's risk perception and individual's skill mastering on European student's, potential family business heir, career choice intention.

\section{Literature review and hypotheses}

Transition process is understood to be one of the most sensitive challenges for a family business (Blumentritt, Mathews, and Marchio 2012). Attracting and motivating a potential heir for succession is a difficult task (Neubauer and Lank 2016). Children with family business background are raised in a very specific environment. Their parent are usually owners and managers of a family business. They dedicate most of their time to the firm since it is the source of family wealth, which should insure a longtime financial stability. Time spent with children is forcefully limited. This situation may influence the heir's perception of family firm or even entrepreneurship, if we recognize a family firm as a proxy for the entrepreneurship. The perception can be positive or negative since they could feel neglected and blame the firm for their situation (Carr and Sequeira 2007). Family businesses long-term goal is to grow the family wealth. This fact differentiates it from other companies. It is also a responsibility for a potential successor at the same time and it could be perceived as an opportunity or a heavy burden (Schröder, SchmittRodermund, and Arnaud 2011). Taking over the family firm comes with important limitations like working closely with other family members and not being able to implement all of the ideas. A new start-up on the other hand, allows choosing the area of interest independently but also requires more skills, more resources and involves a higher level of risk (Schröder, SchmittRodermund, and Arnaud 2011). From the heir's perspective, making a career choice is struggling, since they are torn between the natural need for helping 
their family and choosing the career path, they really want (Murphy and Lambrechts 2015).

Psychology literature proved intention to be the best predictor of planned behavior. That is the reason why career choice models focused on intentions have been the subject of interest in entrepreneurship research (Krueger and Carsrud 1993). Career intention in these models is recognized as an immediate antecedent of behavior. Intentions themselves are determined by attitudes and attitudes are formed by exogenous influences like traits and situational variables (Ajzen 1991). Our study positions entrepreneurship education, risk attitudes and entrepreneurial skill mastering as exogenous influences on career choice intention.

Entrepreneurship is a learning process and entrepreneurial intentions are not spontaneous activities. They are created and so they can be influenced (Krueger Jr., Reilly, and Carsrud 2000). Intentions are the best predictors of actual behavior (Ajzen 2002). Entrepreneurial intentions are consequently important for understanding the entrepreneurial process (Wang and Wong 2004). University environment and its support for the entrepreneurial behavior play an important role for student's entrepreneurial motivation. Education is recognized to be an important factor influencing career intention (Donckels 1991). Specialized courses in entrepreneurship may give people confidence the need for starting-up a new venture (Dyer 1994). Entrepreneurhip education should improve the perceived feasibility for entrepreneurship by increasing the knowledge of students as well as building self-confidence (Krueger and Brazeal 1994). It also should improve the desirability for entrepreneurship by showing students that entrepreneurial activities are highly appreciated. Still, previous studies mostly focused on the effect of general education and just few of them targeted entrepreneurial education, particularly at university (Byabashaija and Katono 2011). In addition, most of the previous studies have focused on the classical career choice dilemma and did not found a significant correlation between entrepreneurship education and student's career choice intention (Wu and $\mathrm{Wu}$ 2008). Entrepreneurship education is the process of providing individuals with the concepts and skills to recognize opportunities overlooked by others and to act where other hesitated (McIntyre and Roche 1999). In this context, we refer to entrepreneurship program as a broader concept than just a number of courses. Moreover, we address entrepreneurship education as a portfolio of complementary activities, which offer a formal entrepreneurial education and an informal support for individual's entrepreneurial attitude. Based on that background we propose our first hypotheses: 
H1: More entrepreneurial supportive educational programs results in preferring new venture to the family business succession and succession to the employment.

An entrepreneur clearly needs to master a wide range of skills for successfully managing the entrepreneurial opportunity and the company. Without them it is difficult to start a business. Previous research confirmed that social values regarding entrepreneurship as well as personal skill perceptions, both influence individual's entrepreneurial intentions. The role of perceived skills is confirmed to be more relevant from both (Liñán 2008). There is an obvious connection between skills and perceived behavior control which results with the fact that individuals who believe they have a high level of skill mastering will more probably feel capable of creating a new firm (Liñán 2008). Entrepreneurial skill perception indicates the level of confidence in relation to entrepreneurial activities. The specific skills we considered in this paper have been taken from previous studies (Zhao 2005; Chen, Greene, and Crick 1998; Liñán 2008; Kickul et al. 2009). These skills can be associated with higher individual's attraction to entrepreneurship. In this context we proposed our second hypotheses:

H2: Higher level of individual's entrepreneurial skill mastery results in preferring new venture to the family business succession and succession to the employment.

Risk taking is another inseparable dimension of entrepreneurial activity. Uncertainty play an important role in every economic decision (Caliendo, Fossen, and Kritikos 2009). Understanding individuals' attitude towards risk is correlated to economic behavior prediction (Dohmen et al. 2011). Since family wealth and business constantly interlace in family firms, risk-taking affects these firms significantly. Individuals consider risk levels whenever evaluating career choices. Higher tolerance towards risk leads to more intense self-employment intention (Douglas and Shepherd 2002). Perception of risk in a specific situation may differ widely from one individual to another. We can conclude that more experienced people with greater knowledge in the field of self-employment tend to perceive a lower level of risk in connection to certain decisions (Caliendo, Fossen, and Kritikos 2009). We presume that students with family business background are more knowledgeable and more experienced since they grew up in family business environment. Family business is already developed to a certain level, so it may be perceived as 
more stable than a new start-up. Based on that we propose our third hypotheses:

H3: Higher level of perceived risk related to entrepreneurship results in preferring employment to the succession and succession to the new start-up.

\section{Data and methodology}

We used dataset from GUESSS 2014 (Global University Etrepreneurial Spirit Student's Survey). The survey in its part covers family business succession. The complete data set has more than 109.000 valid responders from 34 countries. With the goal of preventing a potential multiple response bias, the anonymous survey was carried as an on-line identification-based data collection. For the purpose of this paper we isolated 23.485 student responders from 18 European countries (Great Britain, Germany, Luxemburg, Netherlands, Switzerland, Austria, Belgium, Denmark, Spain, Finland, France, Italy, Portugal, Slovenia, Romania, Poland, Estonia and Hungary).

Table 1: descriptive statistics

\begin{tabular}{|l|l|r|r|}
\hline & & $\mathrm{N}$ & Percentage \\
\hline \multirow{3}{*}{ Dependand value } & Employee & 8.828 & $88,7 \%$ \\
\cline { 2 - 4 } & Entrepreneur & 632 & $6,3 \%$ \\
\cline { 2 - 4 } & Successor & 495 & $5,0 \%$ \\
\hline \multirow{2}{*}{ Gender } & Male & 3.742 & $37,8 \%$ \\
\cline { 2 - 4 } & Female & 6.161 & $62,2 \%$ \\
\hline All participants & & 9.955 & $100 \%$ \\
\hline
\end{tabular}

Source: own research

Since there still isn't a commonly accepted definition of family business we adopted the definition according to which family business is a business where majority share is owned by one or more members of the same family (Barnes and Hershon 1976). Our study includes only students with one or both selfemployed parents. We also excluded all students who already have their own company to avoid survivor bias characteristic for retrospective studies (Gartner 1989). The question, which targeted our dependent variable, had four possible answers (an employee, an entrepreneur, a successor or I don't know yet). Student, who could not decide for career choice intention, were also excluded from the study. In this way, we prevented forced decisions. After the data reduction, we obtained 9.955 valid questionnaires. Descriptive statistics is presented in table 1. 
Since our dependent variable is categorical and has more than two possible solutions, the multinomial logistic regression was selected as the most appropriate method for data analysis. The method allows us to compare two solutions with the referential solution. Since the main scope of the study is to analyze family business heir's career choice intention, our reference value for dependent variable is "successor". For the same reason, all our hypotheses have succession intention as a central category. Methods applied in this study were previously successfully used for investigation of similar issues (Zellweger, Sieger, and Halter 2011).

Our regression model consists of three independent variables: Entrepreneurial education measured with 5 items (Souitaris, Zerbinati, and Al-Laham 2007), risk perception measured with 3 items (Pennings and Wansink 2004) and self-assessed entrepreneurial skills measured with 8 items (Liñán 2008; Zhao 2005). All independent variables are measured using 7-point Likert scale from 1 (minimum) to 7 (maximum).

Table 2: Pearson's Correlations

\begin{tabular}{|l|r|r|r|r|r|r|r|}
\hline & Career & Education & Skills & $\begin{array}{c}\text { Risk } \\
\text { perc. }\end{array}$ & Risk att. & gender & $\begin{array}{c}\text { Study } \\
\text { succ. }\end{array}$ \\
\hline Career & 1 & $0,053^{* *}$ & $0,118^{* *}$ & $-0,013$ & $0,141^{* *}$ & $-0,058^{* *}$ & $-0,021^{*}$ \\
\hline Education & $0,053^{* *}$ & 1 & $0,385^{* *}$ & 0,001 & $0,220^{* *}$ & $-0,036^{* *}$ & $0,095^{* *}$ \\
\hline Skills & $0,118^{* *}$ & $0,385^{* *}$ & 1 & $-0,057^{* *}$ & $0,470^{* *}$ & $-0,044^{* *}$ & $0,128^{* *}$ \\
\hline Risk perc. & $-0,013$ & 0,001 & $-0,057^{* *}$ & 1 & $-0,038^{* *}$ & $0,067^{* *}$ & $-0,006$ \\
\hline Risk att. & $0,141^{* *}$ & $0,220^{* *}$ & $0,470^{* *}$ & $-0,038^{* *}$ & 1 & $-0,107^{* *}$ & $0,053^{* *}$ \\
\hline gender & $-0,058^{* *}$ & $-0,036^{* *}$ & $-0,044^{* *}$ & $0,067^{* *}$ & $-0,107^{* *}$ & 1 & $0,044^{* *}$ \\
\hline Study succ. & $-0,021^{*}$ & $0,095^{* *}$ & $0,128^{* *}$ & $-0,006$ & $0,053^{* *}$ & $0,044^{* *}$ & 1 \\
\hline
\end{tabular}

Source: own research

We added three control variables to the model: gender, self-assessed success during studies and general risk attitude. We included gender as a standard control variable. Previous studies showed that mails are more likely to follow the entrepreneurial career compared to women (Zellweger, Sieger, and Halter 2011). We measured study achievements with 7-point Likert scale from 1 (very bad) to 7 (exceptional). We captured risk attitudes with a general risk question: "I am generally a person who is fully prepared to take risks" also measured on 7-point Likert scale (Dohmen et al. 2011).

Variance inflation factor (VIF) was calculated for each independent variable: entrepreneurial education $(\mathrm{VIF}=1,003)$, entrepreneurial skills 
$(\mathrm{VIF}=1,000)$ and risk perception (VIF=1,172). Variance inflation factor is very close to 1 and never even approaches the marginal value of 10,0 , which leads us to the conclusion that multicollinearity does not appear to be a problem (Hair et al. 2010). Pearson's correlations between variables are displayed in table 2. Our respondents were also assured a strict confidentiality to avoid the influence of social desirability concerns (Podsakoff et al. 2003).

\section{Results and discussion}

Results of our regression model are displayed in table 3. Our reference value is "succession" as a career choice. We can see that entrepreneurial oriented education has a highly significant impact on potential heir's career choice intention. Individuals which are exposed to entrepreneurship supportive environment on their university will choose to continue a family business compared to both career alternatives. We can only partly confirm our first hypotheses since we expected that they will prefer a new start-up compared to succession.

As previous studies confirmed, career decision is a complex issue. We could assume that individuals are considering entrepreneurial education in combination with the perception of family business as an already developed and stabile entity. It already has a product, in most cases a vision of the future development, all necessary networks, sales and purchase markets, etc. Once recognizing that they have enough entrepreneurial knowledge, they will prefer a stable family business environment for application of that knowledge. It is possible that a new venture is recognized as much riskier and as such, it does not offer many opportunities to apply specific knowledge. At least in a starting phase when all efforts are focused on market testing, product testing, technology development and highest possible level of flexibility. In our opinion, this question is worth investigating more in detail. It is important to know why students with family business prefer succession compared to a new start-up when exposed to entrepreneurship supportive and oriented educational programs.

Entrepreneurial skills mastering is a highly significant predictor when comparing succession career alternative with employment. Students with higher level of skill mastering will choose a succession path. We can confirm our second hypotheses in this part. The result was expected. On the other hand, we did not obtain a significant result when comparing succession with a new venture start-up. We may conclude that entrepreneurial skills mastering doesn't influence career decision in this part. Once an individual think that he achieved a successful level of entrepreneurial skills mastering, 
other factors jump in for choosing between family business succession and a new start-up.

Table 3: regression coeficients

\begin{tabular}{|c|c|c|c|}
\hline & Variable & Coefficient B & Significance \\
\hline \multirow{7}{*}{ 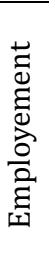 } & Intercept & 3,748 & 0,000 \\
\hline & Entrepreneurial education & $-0,071$ & 0,040 \\
\hline & Entrepreneurial skills mastering & $-0,240$ & 0,000 \\
\hline & Risk perception & 0,034 & 0,339 \\
\hline & Success during studies & 0,160 & 0,000 \\
\hline & Risk attitude & $-0,231$ & 0,000 \\
\hline & Gender (male) & $-0,209$ & 0,027 \\
\hline \multirow{7}{*}{ 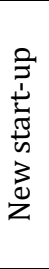 } & Intercept & $-0,294$ & 0,542 \\
\hline & Entrepreneurial education & $-0,109$ & 0,013 \\
\hline & Entrepreneurial skills mastering & $-0,001$ & 0,993 \\
\hline & Risk perception & 0,063 & 0,169 \\
\hline & Success during studies & 0,105 & 0,064 \\
\hline & Risk attitude & 0,100 & 0,048 \\
\hline & Gender (male) & 0,150 & 0,217 \\
\hline
\end{tabular}

Source: own research

This finding is important for parents and business consultants. It is important information to keep in mind when planning the inter-generational transition of a family firm. Skill mastering is by far not enough. It can assure that family's heir will choose an entrepreneurial career path, but it cannot guarantee that he will accept to continue family tradition by taking over the family business. It is worth remembering Ernst\&Young (2011) findings we mentioned in tour introduction. 67\% of existing owners of family firms expect their heirs to continue the legacy, while only $22,7 \%$ of their children actually even think about that possibility. Future research should focus on this gap having in mind our results which clearly shows that entrepreneurial education as well as skill mastering doesn't offer an answer. Parents usually tend to offer a good entrepreneurial education in combination with skill learning (preferably in family firm) with the goal of assuring the successful transition process. Our study shows that it could push the potential heir towards a new start-up. It could give him or her just enough self-confidence for such a move.

Risk perception emerged as not significant factor in our model. Consequently, we reject our third hypotheses. This result is surprising. We expected that risk perception would influence individual's career decision. However, we must admit that we only measured respondents risk perception in relation to entrepreneurship. We didn't measure risk perception related to 
family firm or employment. In our opinion, future studies should think about the survey, which would give a clear answer to this problem. It is possible that in some environments, employment career could be recognized as even more risky compared to an entrepreneurial career path. We can think about family firm succession in similar way.

Our control variable for general risk attitude emerged as highly significant. Respondents, which are keener towards risk will more prefer succession compared to employment and a new start-up compared to succession. This result is expected and as such, it only confirms our previous conclusions related to risk perception. Since general risk attitude significantly influence career choice, specific situational risk perception has to have some influence. Future studies should address this problem obviously with a more complex approach.

We found out that more successful students will prefer both career alternatives compared to family business succession. We could speculate that successful students are more self-confident and as such, they are keener to achieve independence. It should be said that our result for the comparison between succession and a new start-up isn't significant, but it is worth mentioning since the significance level is $6,4 \%$. It is still low probability of making the first order mistake. This result is also interesting for parents, educational institutions and business consultants. Of course, we are not saying that it is better not to motivate a potential heir for successful studying. It is just important to be aware of all factors influencing heir's career choice intention and of the manner in which they influence the choice.

According to our results men, compared to woman are more likely to choose a succession career than employment. We didn't detect a significant relation when comparing succession and a new venture start-up.

\section{Conclusion}

Every entrepreneurial process starts with an entrepreneurial intention in some point of time. Students are expected to make their career choice after the studies. This period could be very challenging for students with family business background. Their families struggled to keep the family business healthy and to enable them to finish their studies. The family usually expects them to help and to eventually take over the whole business. Students, potential successors, also feel a natural tendency to help their family. However, there are several other factors influencing a young individual career choice intention, which doesn't necessarily coincide with family expectations. 
Our paper contributes to better understand the motives for potential successor's career choice intentions. We focused on entrepreneurial education, entrepreneurial skills mastering and individual's risk perception. Results obtained with our analysis are useful for family business owners (parents), business consultants and institutions, especially universities. This relatively narrow scientific field is gaining importance with the globally growing importance of family businesses and SME in general.

\section{References}

Ajzen, Icek. 1991. "The theory of planned behavior." Organizational Behavior and Human Decission Processes 50 (2): 179-211.

Ajzen, Icek. 2002. "Perceived behavioral control, self-efficacy, locus of control, and the theory of planned behavior." Journal of Applied Social Psychology 32: $1-20$.

Astrachan, Joseph H. and Melisa Carey Shanker. 2003. "Family Businesses' Contribution to the U.S: Economy: A Closer Look." Family Business Review 16 (3): 211-219.

Barnes, Louis B. and Simon A. Hershon. 1976. "Transferring Power in The Family Business." Harvard Business Review 54 (4): 105-114.

Bindu Kota, Hima and Ramanjeet Singh. 2016. "Comparative analysis of family businesses with non-family businesses: Empirical evidence from India." Serbian Journal of Management 11 (1): 29-41.

Bird, Barbara, Harold Welsh, Joseph H. Astrachan, and David Pistrui. 2002. "Family Business Research: The Evolution of an Academic Field." Family Business Review 15 (4): 337-350.

Birley, Sue. 2002. "Attitudes of owner-managers' children towards family and business issues." Entrepreneurship Theory and Practice 26 (3): 5-19.

Blumentritt, Tim, Timothy Mathews, and Gaia Marchio. 2012. "Game Theory and Family Business Succession: An Introduction." Family Business Review 26 (1): 51-67. 
Byabashaija, Warren and Isaac Katono. 2011. "The impact of college entrepreneurial education on entrepreneurial attitudes and intention to start a business in Uganda." Journal of Developmental Entrepreneurship 16 (1): 127144.

Caliendo, Marco, Frank M. Fossen, and Alexander S. Kritikos. 2009. "Risk attitudes of nascent entrepreneurs-new evidence from an experimentally validated survey." Small Bus Economy 32: 153-167.

Carr, Jon C. and Jennifer M. Sequeira. 2007. "Prior family business exposure as intergenerational influence and entrepreneurial intent: A Theory of Planned Behavior approach." Journal of Business Research 60: 1090-1098.

Chen, Chao C., Patricia G. Greene, and Ann Crick. 1998. "Does entrepreneurial self-efficacy distinguish entrepreneurs from managers?" Journal of Business Venturing 13 (4): 295-316.

De Massis, Alfredo, Jess H. Chua, and James J. Chrisman. 2008. "Factors Preventing Intra-Family Succession." Family Business Review 21: 183-199.

Dohmen, Thomas, David Huffman, Jurgen Schupp, Armin Falk, Uwe Sunde, and Gert G. Wagner. 2011. "Individual risk attitudes: Measurement, determinants, and behavioral consequences." Journal of the European Economic Association 9 (3): 522-550.

Donckels, Rik. 1991. "Education and entrepreneurship experiences from secondary and university education." Journal of Small Businesses \& Entrepreneurship 9 (1): 35-42.

Douglas, Evan and Dean Shepherd. 2002. "Self-employment as a career choice: attitudes, entrepreneurial intentions, and utility maximization." Entrepreneurial Theiry and Practice 26 (3): 81-90.

Dyer, Gibb W. 1994. "Toward a theory of entrepreneurial careers." Entrepreneurship Theory and Practice 19 (2): 7-21.

Ernst\&Young. 2012. "Built To Last: Family businesses lead the way to sustainable growt."

http://www.ey.com/Publication/vwLUAssets/Built_to_Last/\$FILE/Built_to_ Last.pdf. Accessed August 20, 2014. 
Gartner, William B. 1989. "Some Suggestions for Research on Entrepreneurial Traits and Characteristics." Entrepreneurship: Theory \& Practice 14 (1): 27-37.

Hair, Joseph F., William C. Black, Barry J. Babin, and Rolph E. Anderson. 2010. Multivariate data analysis. $7^{\text {th }}$ ed. Upper Saddle River: Pearson Education, Inc.

Kickul, Jill, Lisa K. Gundry, Saulo D. Barbosa, and Laney Whitcanack. 2009. "Intuition Versus Analysis? Testing Differential Models of Cognitive Style on Entrepreneurial Self-Efficacy and the New Venture Creation Process." Entrepreneurship Theory and Practice 33 (2): 439-453.

Krueger Jr., Norris F., Michael D. Reilly, and Alan Carsrud. 2000. "Competing models of entrepreneurial intentions." Journal of Business Venturing 15 (5-6): 411-432.

Krueger, Norris F. and Deborah V. Brazeal. 1994. "Entrepreneurial potential and potential entrepreneurs." Entrepreneurship Theory and Practice 18 (3): 91-104.

Krueger, Norris F. and Alan L. Carsrud. 1993. "Entrepreneurial intentions: Applying the theory of planned behaviour." Entrepreneurship \& Regional Development 5: 315-330.

Laspita, Stavroula, Nicola Breugst, Stephan Heblich, and Holger Patzelt. 2012. "Intergenerational transmission of entrepreneurial intentions." Journal of Business Venturing 27 (4): 414-435.

Liles, Patrick R. 1974. New Business Venture and the Entrepreneur. Homewood: Irwin.

Liñán, Francisco. 2008. "Skill and value perceptions: how do they affect entrepreneurial intentions?" International Entrepreneurship and Management Journal 4 (3): 257-272.

Lucky, Ossai-Igwe E., Mohd S. Minai, and Adebayo O. Isaiah. 2011. "A Conceptual Framework of Family Business Succession: Bane of Family Business Continuity." International Journal of Business and Social Science 2 (18): 106-113. 
McIntyre, John R. and Mathieu Roche. 1999. University education for entrepreneurs in the United States: a critical and retrospective analysis of trends in the 1990s. Atlanta, GA.: Center for International Business Education and Research, Georgia Institute of Technology.

Murphy, Linda and Frank Lambrechts. 2015. "Investigating the actual career decisions of the next generation: The impact of family business involvement." Journal of Family Business Strategy 6 (1): 33-44.

Neubauer, Fred and Alden G. Lank. 2016. The Family Business: Its Governance for Sustainability. Springer.

O'Reilly, Jacqueline, Werner Eichhorst, András Gábos, Kari Hadjivassiliou, David Lain, Janine Leschke, Seamus McGuinness, Lucia M. Kureková, Tiziana Nazio, Renate Ortlieb, Helen Russell, and Paola Villa. 2015. "Five Characteristics of Youth Unemployment in Europe: Flexibility, Education, Migration, Family Legacies, and EU Policy." Sage open 1-19.

Pennings, Joost M. E. and Brian Wansink. 2004. "Channel Contract Behavior: The Role of Risk Attitudes, Risk Perceptions, And Channel Members' Market Structures." Journal of Business 77 (4): 697-723.

Podsakoff, Philip M., Scott B. MacKenzie, Nathan P. Podsakoff, and Jeong-Yeon Lee. 2003. "Common Method Biases in Behavioral Research: A Critical Review of the Literature and Recommended Remedies." Journal of Applied Psychology 88 (5): 879-903.

Schröder, Elke, Eva Schmitt-Rodermund, and Nicolas Arnaud. 2011. "Career Choice Intentions of Adolescents With a Family Business Background." Family Business Review 24 (4): 305-321.

Senegović, Iva, Valerija Bublić, and Gordana Ćorić 2015. "Family Business Succession Risks: The Croatian Context." In Family Businesses in Transition Economies: Management, Succession and Internationalization, edited by LéoPaul Dana and Veland Ramadani, 175-198. Cham: Springer.

Sharma, Pramodita, James J. Chrisman, and Jess J. Chua. 2003. "Predictors of satisfaction with the succession process in family firms." Journal of Business Venturing 18 (5): 667-687. 
Souitaris, Vangelis, Stefania Zerbinati, and Andreas Al-Laham. 2007. "Do entrepreneurship programmes raise entrepreneurial intention of science and engineering students? The effect of learning, inspiration and resources." Journal of Business Venturing 22: 566-591.

Turker, Duygu and Senem S. Selcuk. 2009. "Which factors affect entrepreneurial intention of university students?" Journal of European Industrial Training 33(2):142-159.

Wang, Clement K. and Poh-Kam Wong. 2004. "Entrepreneurial interest of university students in Singapore." Technocation 24 (2): 163-172.

Wennekers, Sander, André Van Stel, Roy Thurik, and Paul Reynolds. 2005. "Nascent Entrepreneurship and the Level of Economic Development." Small Business Economics 24: 293-309.

$\mathrm{Wu}$, Sizong and Lingfei Wu. 2008. "The impact of higher education on entrepreneurial intentions of university students in China." Journal of Small Business and Enterprise Development 15 (4): 752-774.

Zellweger, Thomas, Philipp Sieger, and Frank Halter. 2011. "Should I stay or should Igo? Career choice intentions of students with family business background." Journal of Business Venturing 26 (5): 521-536.

Zhao, Fang. 2005. "Exploring the synergy between entrepreneurship and innovation." International Journal of Entrepreneurial Behavior \& Research 11 (1): 25-41. 